\title{
ПСИХОЛОГО-ПЕДАГОГІЧНІ АСПЕКТИ ФОРМУВАННЯ ЗДОРОВОГО СПОСОБУ ЖИТТЯ У СТРУКТУРІ ФІЗИЧНОЇ ПРОФЕСІЙНО-ПРИКЛАДНОЇ ПІДГОТОВКИ МАЙБУТНІХ УЧИТЕЛІВ
}

Андріанов Т. В. Психолого-педагогічні аспекти формування здорового способу життя у структурі фізичної професійно-прикладної підготовки майбутніх учителів.

Статтю присвячено проблемі формування здорового способу життя у структурі фізичної професійно-прикладної підготовки, реалізація якої сприяє накопиченню фахових знань, умінь, навичок, інтересів, мотивів. Зроблено спробу дослідити основні компоненти професійної спрямованості майбутніх учителів фізичного виховання.

Ключові слова: критерії здоров'я, особистість, професійна діяльність, майбутні вчителі, фізичне виховання.

Андрианов Т. В. Психолого-педагогические аспекты формирования здорового образа жизни в структуре физической профессионально-прикладной подготовки будущих учителей.

Статья посвящена проблеме формирования здорового образа жизни в структуре физической профессионально-прикладной подготовки, реализация которой способствует накопление определенных знаний, умений, навыков, интересов, мотивов. Сделана попытка исследовать основные компоненты профессиональной направленности будущих учителей физического воспитания.

Ключевые слова: критерии здоровья, личность, профессиональная деятельность, будущие учителя, физическое воспитание.

Andrianov T. V. Psychological and pedagogical aspects of formation of a healthy lifestyle in the structure of the physical professional-applied preparation of future teachers.

The article is devoted to the problem of formation of a healthy lifestyle in the structure of the physical professionally-applied training that affect the accumulation of specific knowledge, skills, interests, motives. An attempt is made to explore the main components of professional orientation of future teachers of physical education.

Key words: health criteria, personality, professional activity, future teachers, physical education.

Фізична культура і спорт як соціокультурний феномен є визначальним чинником способу життя людини, тому стає зрозумілою складність формування здорового способу життя молодого покоління засобами фізичної активності. Загалом можна констатувати, що поняття «здоров'я» в сучасній науковій літературі розглядається на трьох рівнях функціонування людини: біологічному, психологічному й соціальному. Вказані складники є невід'ємними один від одного, їх цілісна єдність повинна стати головною методологічною позицією в підході до процесу засвоєння й удосконалення людиною цінностей фізичної культури, в основі якої лежить рухова активність особистості. 
Удосконалення системи освіти, іï вплив на соціальне, економічне і духовне життя суспільства значною мірою залежить від рівня професійної майстерності вчителя, його моральних і фізичних якостей. Сучасні вимоги до професійної компетентності вчителя, його практичної підготовки набувають більш вираженого характеру. Стрижнем сучасної освіти та змістом усієї педагогічної практики має стати розвиток не тільки фізичного, а й психічного та соціального здоров'я [3, с. 15]. Важливо, щоб майбутні вчителі володіли різнобічними знаннями про сутність здорового способу життя як інтегрованого явища, були переконані в необхідності його дотримання, глибоко усвідомлювали можливості, потребу і звички в розвитку особистості, уміли протистояти різноманітним негативним впливам, мали бажання i вміння позбутися шкідливих звичок, якщо вони є. Тому формування здорового способу життя (ЗСЖ) у структурі фізичної професійноприкладної підготовки майбутніх учителів $\epsilon$ одним із пріоритетних завдань вищої педагогічної освіти, спрямованої на гуманізацію, усвідомлення особистості як цінності освітянського процесу.

Meта статmі полягає в розкритті психолого-педагогічних закономірностей формування здорового способу життя у структурі професійно-прикладної системи фізичного виховання ВНЗ.

Завдання дослідження:

- означити теоретичну підготовку майбутнього вчителя, зорієнтовану на цінності здорового способу життя;

- з'ясувати вплив навчально-виховного процесу на формування ЗСЖ майбутнього вчителя;

- визначити критерії, рівень сформованості знань, умінь, навичок ЗСЖ майбутнього вчителя.

Роль фізичного виховання у формуванні здорового способу життя майбутніх учителів досліджували А. Афонін, В. Волков, Ж. Ломака, В. Марчик, Е. Павленко, Ю. Ромаскевич, Р. Сіренко, Ю. Суббота, А. Федоров та ін. А. Афонін зауважує, що нині сучасне здоров'я для багатьох - мета, що не досягається. В очікувані часу, коли хвороб не буде, найкращим орієнтиром у прагненні досягти доброго здоров'я та зберегти його на довгі роки, можуть слугувати принципи здорового способу життя [1, с. 11].

Н. Білоконна зазначає, що науковці єдині в думці про тенденцію погіршення здоров'я молоді та легковажного ставлення молодої людини до свого здоров'я. Сучасні вимоги до підготовки освітянських кадрів потребують активізації фізкультурнооздоровчої роботи у вищих навчальних закладах; формування у студентів культури здоров'язбереження як світоглядної орієнтації у структурі цілісного навчальновиховного процесу вищого навчального закладу [2, с. 33].

Аналіз наукових досліджень дає підстави стверджувати, що поза увагою залишається формування здорового способу життя як ціннісної орієнтації особистості. Більш дійовому й ефективному формуванню навичок здорового способу життя в підростаючого покоління, на думку В. Марчик, сприятиме комплекс заходів, спрямований на підвищення рівня морального здоров'я. Через використання засобів, методів і форм організації дисципліни «Фізичне виховання» можливе формування норм, цінностей і правил поведінки у сфері особистої фізичної культури як чинника підвищення рівня духовного розвитку студентства [4, с. 127].

Процес формування здорового способу життя у майбутніх педагогів здійснювався нами поетапно. Умовно ми виокремили три етапи. На першому етапі- оцінноорієнтовному- ми виявили інтереси і ціннісні орієнтації майбутніх учителів, їх ставлення до ЗСЖ, ступінь сформованості здорового способу життя. Здійснювалось розширення і поглиблення системи знань про ЗСЖ і фізичну культуру як одного 3 
основних іï чинників, формування ціннісних орієнтацій професійного й особистісного ставлення майбутніх учителів до власного здоров'я, фізичної культури і ЗСЖ. Крім цього, велось цілеспрямоване переконання в необхідності дотримання ЗСЖ задля найбільш ефективного професійного становлення, особистого добробуту. На другому етапі - програмно-цільовому - задля формування поглиблених знань, практичних навичок і вмінь із ЗСЖ здійснювалась підготовка студентів до ведення самостійних занять 3 фізкультурно-оздоровчої роботи. Водночас, формувалися такі професійно і соціально важливі цінності, як любов до праці, самостійність, сила волі, самодисципліна, наполегливість, витривалість тощо. Якщо на першому етапі формування ЗСЖ студент був більшою мірою об'єктом педагогічного впливу, то на другому етапі він поставав активним суб'єктом перетворювального процесу. На третьому етапі- індивідуалізації і вдосконалення ЗСЖ - кожен студент мав змогу визначити власну програми 3 самоформування ЗСЖ, індивідуалізувати ії, демонструвати свої успіхи й досягнення.

Сформованість ЗСЖ у майбутніх учителів головним чином визначається змістом, організацією і спрямованістю навчальних занять 3 фізичного виховання. Опитування студентів показало, що майбутні педагоги 3 усіх форм занять фізичною культурою надають перевагу передовсім - навчальним заняттям (25\%), а потім самостійним у групі, 3 друзями (18\%.). Із урахуванням цього процес формування ЗСЖ здійснюється комплексно як на навчальних заняттях, так і в позанавчальний час.

Значна частина студентів (51,4\%) основною метою занять 3 фізичної культури вважає складання контрольних нормативів, не бачить необхідності занять фізичною культурою для зміцнення здоров'я і формування ЗСЖ. Тому ми намагалися внести в навчальний процес 3 фізичної культури суттєві корективи - у зміст, а також в організацію, форми, методи і засоби, що відповідають реалізації змісту. Зміст матеріалу теоретичного курсу передбачав професійно-оздоровчу спрямованість навчальновиховного процесу з фізичного виховання, забезпечувався інтерес до самопізнання організму, його функціонування, стану здоров'я.

Велике значення у формуванні в майбутніх учителів здорового способу життя має позааудиторна фізкультурно-оздоровча і спортивно-масова діяльність, яка передбачає методичне забезпечення, підготовку фізкультурного активу, що здійснює керівництво цією роботою, участь студентів в організації і проведенні спортивних змагань, в оглядах-конкурсах. Це надало змогу підвищити фізичну підготовленість, рухову активність i зацікавленість студентів у заняттях фізичною культурою і спортом; залучити їх до самостійних занять фізичними вправами у вільний час і під час канікул; вивчити прийоми контролю і самоконтролю за самопочуттям і своїм фізичним станом.

Для формування ЗСЖ першочергове значення відводиться формуванню у студентів практичних умінь та навичок фізичного вдосконалення і контролю динаміки свого фізичного стану. На практичних заняттях передбачено поєднання різних методів, засобів і форм навчання і виховання, спрямованих на підвищення активності, зацікавленості, усвідомленості виконаних вправ і завдань, самостійності в пошуку педагогічних рішень, виявлення емоційно-вольових якостей, самодисципліни; використання змагальних, ігрових, колових методів, особистий приклад викладача. Створення позитивного настрою, атмосфери доброзичливості і взаєморозуміння між викладачем і студентом у виборі змісту практичних занять і методики його проведення сприяло підвищенню інтересу до них. Підвищення інтересу до навчальних занять відбувалося включенням до їх змісту комплексного поєднання фізичних вправ, видів спорту, що відповідають індивідуальним і груповим запитам студентів. Так, поряд із використанням на навчальних заняттях 3 фізичного виховання «класичних» загально-розвивальних вправ, переважно гімнастичного 
характеру, ми застосовували вправи, спрямовані на розвиток координації, пам'яті, переключення уваги, 3 поступовим ускладненням завдань, а також вправи і рухи 3 музичним супроводом. У студентів особливо яскраво виявляється потреба в колективній участі у фізкультурно-оздоровчій діяльності. Тому для формування згуртованості навчальної групи і вироблення позитивних емоцій використовуються командні ігри: волейбол, баскетбол, ігри-естафети з різними предметами, рухливі ігри без предметів і 3 різними предметами, сюжетні ігри.

На навчальних заняттях передбачено також навчання майбутніх учителів складати індивідуальні життєві програми, орієнтовані на використання елементів ЗСЖ, які дозволяють визначити найефективніші засоби i методи раціонального режиму педагогічної праці і відпочинку, різноманітні можливості проведення дозвілля, організації оптимального рухового режиму, реалізації життєвих планів і цілей.

Отже, вивчення стану навчально-виховного процесу з фізичного виховання дозволило виявити в життєдіяльності майбугніх учителів основні складники ЗСЖ. До них належать: культура навчальної праці з елементами іï наукової організації; організація режиму харчування, сну, перебування на свіжому повітрі, що відповідає санітарно-гігієнічним вимогам, організація індивідуального доцільного режиму рухової активності; змістовне дозвілля, що має розвиваючий вплив на особистість; подолання згубних звичок (алкоголь, куріння, токсикоманія тощо), культура міжособистісного спілкування і поведінки в колективі; культура самоуправління і самоорганізації. Усі вказані вище елементи ЗСЖ проектуються на особистість студента, його життєві плани, цілі, запити, поведінку. Стимулюванням професійного ставлення студентів $є$ створення ситуації успіху, яка викликає позитивні емоції, переборює психологічні труднощі та задовольняє творчу діяльність.

Аналізуючи результати дослідження, зазначаємо, що здоровий спосіб життя грунтується на передовому науково-педагогічному досвіді і вміщує такі компоненти, які відповідають традиціям і сучасним формам та методам системи фізичного виховання.

Професійно-прикладна фізична підготовка спрямована на підвищення рівня професійно важливої фізичної і психологічної підготовленості майбутніх фахівців та зв'язок їх професійної діяльності 3 педагогічними навичками теорії i методики фізичного виховання.

Програма фізичного виховання студентів вищих навчальних закладів (ВНЗ) переважно зорієнтована лише на розвиток певних фізичних якостей. Тому для розв'язання завдань поставленої проблеми нами проведено комплекс досліджень, які передбачали: виявлення реального стану здорового способу життя серед майбутніх учителів; корекційну роботу, що передбачала складання і реалізацію виховних профілактичних фізкультурно-оздоровчих заходів, спрямованих на покращення стану здоров'я; консультування студентів з питань здорового способу життя; вплив на емоційно-вольову і мотиваційно-ціннісну сферу життєдіяльності майбутніх педагогів 3 урахуванням їхніх індивідуальних і колективних запитів.

Задля набугтя необхідних теоретичних знань у майбутніх педагогів щодо здорового способу життя передбачалося: навчання самостійного складання індивідуальної програми ведення ЗСЖ і використання іiі в професійній діяльності і повсякденному житті, опанування навичками самоконтролю, самовиховання і самовдосконалення; виховання у студентів потреби у веденні ЗСЖ як основи фізичного, психічного і морального благополуччя, а також для майбугньої роботи вчителя, здатного розв'язувати оздоровчі, освітні і виховні завдання з колективом класу і школи загалом.

Нами визначені педагогічні умови, які забезпечують найбільш повноцінне формування ЗСЖ у майбутніх учителів: формування особистісного сенсу занять на основі розвитку практичних умінь на базі теоретичних знань, культурного середовища, 
матеріальних можливостей; орієнтації на норми, цінності, зміст ЗСЖ, що регулюють життєдіяльність майбутніх учителів; комплексний підхід до фізичного виховання 3 єдністю теоретичного і практичного компонентів, включаючи проблему одночасного формування знань і вмінь самостійно виконувати фізичні вправи.

Навчально-виховний процес $з$ фізичного виховання студентів, які брали участь у дослідно-експериментальній роботі, супроводжувався тестування, анкетування, спостереженням, за результатами яких визначено критерії сформованості у майбутніх учителів здорового способу життя: пізнавальний (засвоєння теоретичних знань про здоровий спосіб життя); мотиваційний (усвідомлення цінності здоров'я); діяльнісний (досягнення нормативних показників фізичної підготовленості).

Пізнавальний критерій сформованості ЗСЖ виражався у теоретико-методологічній обізнаності студентів щодо здорового способу життя: наявність теоретичних знань щодо ведення здорового способу життя; вміння виокремлювати на основі базових знань складники здорового способу життя; вплив здорового способу життя на здоров'я особистості; вміння контролювати власний спосіб життя.

Мотиваційний критерій сформованості ЗСЖ виражався у ціннісному ставленні студентів до власного здоров'я, а саме: в усвідомленні цінності здоров'я і залежності його від способу життя; у позитивному сприйнятті здорового способу життя; у прагненні до втілення оздоровчих методик у спосіб життя.

Діяльнісний критерій сформованості ЗСЖ виявлявся в готовності студента до виконання основних компонентів здорового способу життя; у вмінні застосовувати фізичні вправи задля самооздоровлення; в органічному поєднанні науково обгрунтованих і нетрадиційних методик оздоровлення.

Формування здорового способу життя майбутніх учителів під час проведення занять 3 фізичної культури - це базова інваріантна діяльність - запорука розвитку навчальних та спеціальних здібностей, що покладено в основу всієї навчальної діяльності студентів у процесі фізичного виховання, який виховує звичку до систематичних занять фізичними вправами та культуру життєдіяльності.

Психолого-педагогічні дослідження необхідно проводити у природних умовах (заняття, спортивно-масові та оздоровчі заходи), оскільки лише така організація навчального процесу дозволяє зафіксувати не кількісні, а якісні зміни у формуванні ЗСЖ у навчально-виховному процесі.

Систематичне проведення спеціальних заходів, спрямованих на формування ЗСЖ майбутніх учителів, сприяє підвищенняю рівня їх фізичного стану та навичок здорового способу життя.

Процес формування ЗСЖ майбутніх учителів буде ефективним за таких психолого-педагогічних умов: посилення теоретичних та практичних знань, умінь i навичок; зорієнтованість студентів на організацію і проведення спортивно-масових i оздоровчих заходів; спрямування сучасної системи фізичного виховання на становлення творчої особистості.

\section{Література}

1. Афонин А. П. Проблемы здоровья человека /Анатолій Петрович Афонин // Матеріали наук.-практ. конф. [«Актуальні питання формування здорового способу життя дітей, підлітків та молоді»] (Кривий Ріг, 10 квітня 2009 р.) / М-во освіти і науки України, Криворізький державний педагогічний університет.- Кривий Ріг: КДПУ, 2009. - С. 8-11. 2. Білоконна Н. І. До проблеми збереження здоров'я студентів вищої педагогічної школи / Н. І. Білоконна, С. П. Білоконний // Матеріали регіон. наук.-практ. конф. [«Здоров'я дітей, підлітків, молоді та здоров'язберігаючі технології в освіті»], (Кривий Ріг, 6 квітня 2012 р.) / М-во освіти і науки України, Криворізький педагогічний 
інститут ДВНЗ «КНУ». - Кривий Ріг, 2012. - С. 30-33. 3. Кравцова І. А. Використання здоров' язбережувальної технології у процесі навчання - основна вимога до професійної компетентності вчителя початкової школи / І. А. Кравцова // Матеріали регіон. наук.практ. конф. [«Здоров’я дітей, підлітків, молоді та здоров’язберігаючі технології освіті»] (Кривий Ріг, 6 квітня 2012 р.) / М-во освіти і науки України, Криворізький педагогічний інститут. - Кривий Ріг: КПІ ДВНЗ «КНУ», 2012. - С. 12-15. 4. Марчик В. І. Холістична модель здоров'я в основі формування здорового способу життя / В. І. Марчик, T. В. Андріанов, В. С. Андріанов // Матеріали VII між. наук.-прак. конф. [«Реалізація здорового способу життя - сучасні підходи, присвячена 140-річчю від дня народження Івана Боберського»] (Дрогобич, 16-17 травня 2013)/ М-во освіти і науки України, Дрогобицький державний педагогічний університет імені Івана Франка. - Дрогобич: дДПУ, 2013. - С. 126-131.

\section{ОЦІНКА ЗНАНЬ СТУДЕНТІВ В УМОВАХ КРЕДИТНО-МОДУЛЬНОЇ СИСТЕМИ НАВЧАННЯ}

Антоненко I. I. Оцінка знань студентів в умовах кредитно-модульної системи навчання.

У статті розкрито особливості тестування за допомогою комп’ютера. Обгрунтована структура тестів для оцінки знань студентів в умовах кредитно-модульної системи навчання за Болонською системою. За результатами дослідження рекомендовано комп'ютерний метод оцінки знань студентів на базі програми «Асистент».

Ключові слова: оцінка знань, структура тестів, кредитно-модульна система навчання, комп'ютерне тестування, кількість запитань.

Антоненко И. И. Оценка знаний студентов в условиях кредитно-модульной системы обучения.

В статье раскрыты особенности тестирования с помощью компьютера. Обоснована структура тестов для оценки знаний студентов в условиях кредитно-модульного обучения согласно Болонской системы. По результатам исследования рекомендован компьютерный метод оценки знаний студентов на базе программы «Ассистент».

Ключевые слова: оценка знаний, структура тестов, кредитно-модульная система обучения, компьютерное тестирование, количество вопросов.

Antonenko I. I. The assessment of the students in credit-modular system.

The features of testing were revealed by computer. The structure tests were substantiated to assess student's knowledge in a credit-modular training in accordance with the Bologna system. As a result of research the computer method of estimation of knowledges of students is recommended on the base of the program «Assistant».

Key words: assessment of the knowledge, the structure of tests, the credit-modular system of training, computer testing, amount of questions.

Сучасна педагогічна наука накопичила чималий досвід використання інформаційних технологій у системі освіти $[1 ; 2 ; 3]$.

В умовах європейської інтеграції необхідно моделювати методи оцінки знань відповідно до Європейської кредитно-трансферної системи (ECTS). У навчальному 